\title{
Hybrid Learning Aided Technology-Rich Instructional Tools - A Case Study: Community College of Qatar
}

\author{
Muhammad J. Shehab, Student Member, IEEE, Network Engineer, \\ Information Technology Department, Community College of Qatar, Email:MuhammadJShehab@gmail.com
}

\begin{abstract}
Educational Institutions have an essential role in promoting the teaching and learning process, within universities, colleges, and communities. Due to the recent coronavirus COVID 19 pandemic, many educational institutions adopted hybrid learning (HL), which is a combination of classic and online learning. It integrates the advantages of both, and it is a fundamental factor to ensure continued learning. Technological innovations such as HL are changing the teaching process, and how students, lecturers, and administrators interact. Based on this, the Community College of Qatar (CCQ) focused on researching the structures and elements related to the adoption of HL. Thus, the goal of this research paper is to reveal the impact of HL on the learning process in CCQ, and the effective didactic tools required for a successful HL program. Our research questions for assessing and evaluating the learning process at CCQ are as follows: a) Is HL a suitable learning strategy that would best suit the students ?; b) What are the didactic tools needed in the HL program at CCQ ?; c) Will the students meet the learning objectives if HL program is adopted?. A quantitative method was used in this study. Furthermore, a questionnaire was designed for the survey which was designed to measure the opinions of the students, instructors, and administrators about the HL program. It is observed from the results that the majority of students, instructors, and administrators showed a positive attitude toward HL, but some had negative views and experienced challenges. The results were analyzed and discussed to better utilize HL to meet the growing demands of the community.
\end{abstract}

Index Terms-Hybrid Learning (HL), Curriculum Strategy (CS), Interdisciplinary, Technology Integration, Online Learning, Face-to-Face (F2F) Learning, COVID-19, Student Attitude.

\section{INTRODUCTION}

The breakthrough out of the coronavirus COVID-19 pushed the hybrid learning (HL) forward since it mingles the advantages of both the face-to-face (F2F) classroom teaching and online learning as shown in Fig 1. HL is now considered as a key element to ensure continued education [1]. The fundamental redesign of the educational process at the Community College of Qatar (CCQ) based on HL program requires the need to address the challenges associated with this new program, since the motif of HL is not only a simple mix of F2F and online instruction, but rather a focus on enhancing the accomplishment of learning and teaching objectives by employing the "appropriate" didactic technologies to match the "appropriate" learning to the "appropriate" person at the "appropriate" time [2].

With the increasing advancements in the instructional technology (INST), academic institutions over the world seek to integrate technologies and resources to facilitate the teaching

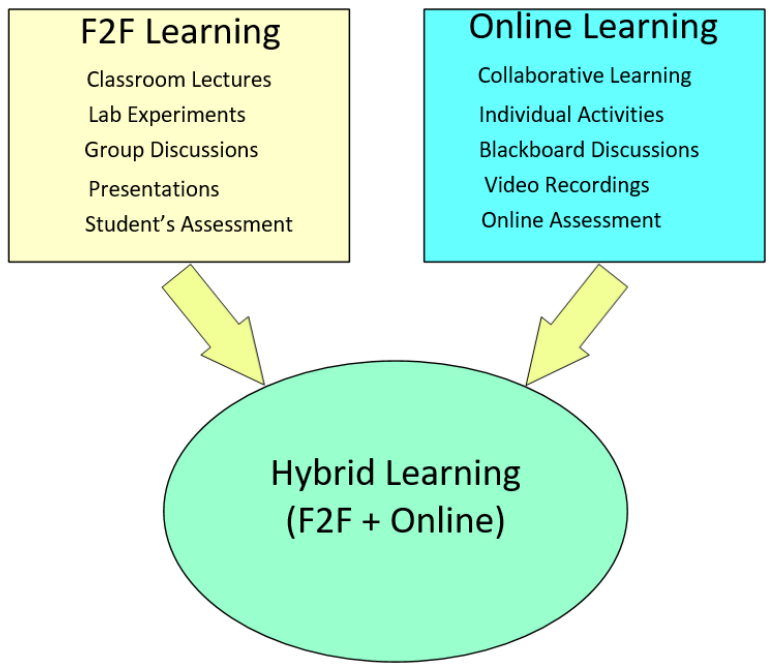

Fig. 1: Hybrid Learning

and learning process, make it more practical, interesting and attractive in order to enhance the active learning strategies (ALSs), especially in the presence of hybrid learning which combines both F2F and online instruction simultaneously. Furthermore, one of CCQ's goals is to aspire to motivate, and to transform to become an educational institution that provides students with the latest educational tools and platforms, and the adoption of HL accelerates the process [3]. The idea of HL may be intuitively simple, but practically it is complex. The reason is that the instructor needs to reduce the F2F meetings and replaces it with a huge amount of instructional time in addition to online activities [4]. Hybrid classes focuses on online activities to assist students in learning and practicing, in addition to their participation in a F2F classroom. Thus, the students will be active, and this will strengthen their technological background by using the computer, smart phone, tablet and learning management systems (LMS) such as Blackboard. HL provides students with flexibility and this will assist students in studying faster and possessing worthy INST skills. Further, HL will furnish the students with the required skills to think and work independently. This will strengthen them to overcome the challenges in future, which is aligned with the Qatar National Vision (QNV) 2030 [3]. 


\section{A. Research Aim and Objectives}

This research aims to investigate the impact of HL on the educational process in $\mathrm{CCQ}$, in addition to exploring the information and communication (ICT) technologies used to enhance the educational process and guarantee the success of HL program. Our research will be based on the following questions:

- Is HL a suitable learning strategy that would best suit the students

- What are the didactic tools needed in the HL program at CCQ ?

- Will the students meet the learning objectives if $\mathrm{HL}$ program is adopted?

In order to answer these research questions in this study, a survey was designed and developed to evaluate the student's awareness and involvement in HL program. The findings are then discussed and analyzed in order to set recommendations to empower the HL program in CCQ.

\section{B. Research Methodology}

This research paper is a case study approach for CCQ. A quantitative method was utilized in this paper to meet the objectives of this research. Thus, surveys are performed as an evaluation tool to measure the students' and instructors' level of awareness, concerns, opinions, behaviors and their willingness to participate in the HL program. This is to understand to what extent the students and instructors are satisfied with this program, and data is generated based on these surveys. Moreover, the appropriate information is collected through research and literature review to answer the research questions as well. The literature review on HL was conducted in order to satisfy the requirement of this study. Finally, recommendations are given based on the findings in order to answer the research questions and to verify the effectiveness of HL strategy, taking into considering the limitations encountered during the analytical process.

\section{Literature REVIEW}

The components of hybrid learning are the F2F learning and the online learning. There is difference between learning in classrooms F2F and online virtual sessions. In F2F classrooms learning, the communication is verbal with real-time body language, visual cues, and F2F context. However, in online virtual sessions the communication between the instructor and the students occurs in virtual form with video conferencing and written text format without the presence of the body language and visual cues factors [5]. Nonetheless the advancements and deployments of the instructional technologies in the learning process is evolving. Nowadays, students and instructors are familiar with the digital technology. Thus, instructors are encouraged to utilize the didactic tools and Information technology (IT) applications in teaching to encourage and stimulate student's learning [6]. HL involves various learning strategies since it provides educational productivity, reduced cost, personal growth, knowledge awareness, joint participation, and collective collaboration. Further, HL resolves physical attendance problems and simplifies corrections [7]. It reinforces learning and adds motivation, interactivity, social interactions, and leads to enhanced feedback and use of study materials [8].

Actually, HL is anticipated to become the new learning model that utilizes various media resources to empower the interaction between the students [9]. For example, it provides significance and motivating learning tools through various teaching methods such as social networking, blog, webinars, forums, live chats, etc. which provides students with more opportunities to express and give a feedback [10]. Learning management systems (LMS)s such as WebCT, Moodle and Blackboard facilitates the migration toward HL. The didactic tools are utilized to enable the collaborative learning between the lecturers and the students [11].

It is shown in Fig 1 that HL program involves online activities such as collaborative learning, individual activities, studying video recordings, online presentations, Blackboard discussions, and online assessment [12]. More, it includes F2F instruction such as lab experiments, class lectures, group discussions, presentations, and class assessments [13]. The recent development of HL focused on optimizing the outcome of the learning process. Therefore, previous studies evaluated the effectiveness of HL compared to the online teaching and traditional teaching [14]. Moreover, while there are research studies on HL, studies that focused on the implementation and adoption of HL are still limited, and this is a gap to be addressed. Furthermore, some studies on HL focused on surveys for students only. However, in our case study, we will focus on CCQ adoption to HL, how the didactic tools supports HL, and how students, lecturers, and administrators interacts when HL is adopted. We performed three surveys for administrators, instructors, and for students who are involved in the HL program, and based on these surveys we will discuss the cons and precons of the HL and how to address the findings of the survey in order to better employ HL to meet the growing demands of the college and the community.

\section{SURVEY ANALYSIS}

\section{A. Survey Context}

Three surveys for students, instructors, and administrators took place at CCQ in Qatar. Data was gathered from several hybrid courses taught by CCQ instructors during spring 2021. There are different courses taught in a hybrid format such as the Business Computer Applications course (BCIS 1305) and Computer Fundamentals (ITEC 1300). The focus of the BCIS course is on business applications of software including Microsoft word, Excel, PowerPoint, Teams, Streams, and business-oriented utilization of the Internet. It is a 3 credit hours course, introductory, and needs no prerequisites. This course is designed to equip students with learning environments in order to master the fundamentals of computer skills which are important in dealing with technology as an educational tool in their future studies (See Appendix A). It was taught by different instructors during spring 2021. The second course which is the computer fundamentals, provides an overview on computers and computer literacy. This course 
is also 3 credit hours and focuses on the history of computing, personal computers, and computer components including hardware, input, output, system software and applications.

\section{B. CCQ Didactic Tools Utilized In The Learning Process}

The main Didactic Tools used in CCQ for online and hybrid education are the Blackboard, Banner, Microsoft Team, and Cisco Webex.

1) Blackboard: It is a LMS that includes many important zones such as the:

- Content Zone: This includes the instructor's contact info, course material, learning module, class recordings, syllabus, rubrics and announcements.

- Assessment Zone: This includes quizzes, tests, assignments, surveys, and review a graded paper.

- Communication Zone: This includes the discussion board, emails, chats and class rosters.

- Student's Zone: Students have access to check their grades, make a personal homepage, calendar, and profile.

Blackboard assists in making the learning process paperless. Thus, the instructor can share with students the syllabus, lectures, power points, and video recordings. More, teachers can utilize Blackboard to assess students by giving homeworks, quizzes, and exams. This is a significant tool in online and hybrid learning which helps in managing the learning process effectively [5].

2) Banner: Banner is student information systems (SIS) which is considered as vital in the learning process. It is used to schedule classes and classify it whether it is F2F, online, or hybrid. This system can be also used to track attendance, extract attendance record, summary class list, view class schedule, view assignment history, add Midterm and final grades.

3) Microsoft Teams: MS teams is one of the most popular and important Microsoft office 365 tool that serves participants for online virtual classes with many features and easy functions such as audio call, video conference, whiteboard, and web chat. Further, one can organize his meeting calendar and form teams. MS teams, can be linked to Blackboard in which the instructor can share the MS teams meeting link with all students on Blackboard. This online virtual link on Blackboard can be used by students to join the MS teams online session. Moreover, MS teams offers breakout classrooms to aid instructors in establishing meaningful connections via smaller and comfortable group settings. This feature enables students to be separated into groups to enhance foster collaboration, facilitate discussions, and motivate participation. Hence, MS teams application enhances experience and education at CCQ and it is very important for hybrid and online learning [15].

4) Cisco Webex: Cisco Webex is a modern platform used for online virtual classes with rich options and features in addition to its high performance. It facilitates virtual learning and HL which enhances the collaboration and engagement of the instructor and students. Furthermore, it enables you to have education anytime and anywhere for connected classrooms, and thus it improves the students' outcomes since it mixes synchronous and asynchronous learning [16].

\section{Participants}

The participants in this survey were the instructors, students, and administrators. The number of students that participated in this survey in spring 2021 is 116 from two hybrid courses which are the BCIS course and the Computer Fundamentals course. The BCIS hybrid course is divided into three classes with 46 students in the first class, 36 students in the second class, and 16 students in the third class. Further, the number of students in the Computer Fundamentals course is 18. Thus, the total number of students that participated in this survey is 116 . These students are undergraduate from different disciplines and various departments. They had the experience of taking hybrid courses. Eighty eight of the students are female and twenty eight of the students are male, which means that the female students percentage is 76 percent and the male students parentage is 24 percent. Their ages range between 20 and 50 years old. Further, the students' GPAs is between 2 and 4, with a median of 2.7 in a scale of 4 . Moreover, the number of instructors and administrators that taught hybrid courses and participated in this survey is 18 and 23 respectively. These instructors had the experience of teaching hybrid, online and F2F courses. Therefore, the total number of participants is 157 .

\section{Information Collection and Analysis}

The information collected from CCQ staff was based on three hybrid course surveys for the instructors, students, and administrators (see Appendix B). These surveys were focused on three main sections using a 5-point likert scale, the first section was about the educational technology background of the students and instructors as well as the benefit and usage of Blackboard tools for them. The second section was about the experience of students, instructors, and administrators with CCQ HL program. Further, we have taken into consideration their recommendation for the HL program in future. Data analysis included quantitative method with descriptive statistics needed to analyze the survey questions. This included calculating the frequency, percentages, means, and standard deviations.

\section{RESUlts AND Discussions}

The total number of participants in this survey is 157, around $74 \%$ of them are students, $15 \%$ are administrators, and $11 \%$ are instructors as shown in Fig 2. Further, Fig 3 reveals that the percentage of females that participated in this survey is $62 \%$ where as that of males is $38 \%$. The focus on these surveys was on the views of students, instructors, and administrators about the HL program in CCQ, and whether they found this program successful or not. Based on the survey results, the students, instructors, and administrators showed 
positive attitude toward HL process. We will start with the results of the first survey which was about the educational and informational technology background for the students and instructors in CCQ.

\section{A. First Survey about the Technology Background for Students and Instructors:}

Table I below shows descriptive statistics for this survey, and from these results we can infer that the the majority of the students and instructors have acceptable background in technology. The mean of the survey results in table I for the student's educational technology background ranges between 3.57 and 3.72 which is acceptable and the standard deviation ranges between 0.8 and 0.97 , whereas for the instructors' educational technology background the mean ranges between 4 and 4.55 and the standard deviation ranges between 0.67 and 0.89 . This reveals that the instructors' informational technology background is solid. For the second part of table I which is about the benefits of blackboard tools for the students and instructors, the mean ranges between 4.18 and 4.38 which reflects a very good indication for the students' interest in blackboard tools, and that for instructors is between 4.17 and 4.67. This shows the enormous benefit blackboard is offering as an INST tool.

\section{TOTAL NUMBER OF PARTICIPANTS IN THE SURVEY}

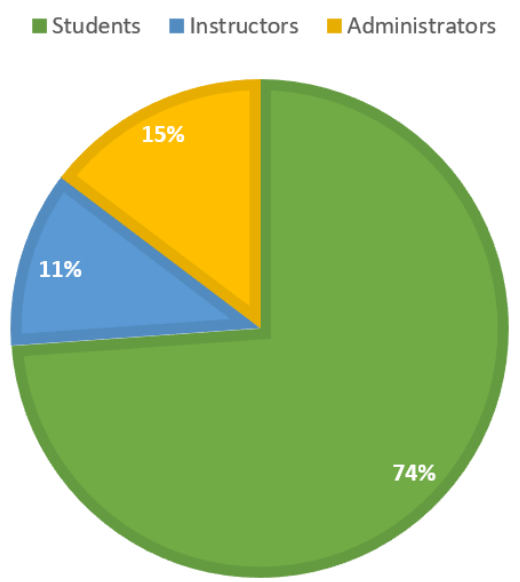

Fig. 2: Total Number of Participants in the Survey

Besides, from the Microsoft office suite, we realize that the students are more experienced in word, excel and power point more than teams and streams. The reason is that they used to utilize word, excel and power point in their practical work or study, but they recently started using teams and streams for educational purpose in online and hybrid learning processes. Teams software is used in online and hybrid learning for lectures, meetings, presentations, and exams. Further, streams software is for the recordings of lectures where the instructor can upload the lecture recorded and the students can watch these recordings for lecture review.

\section{Percentage of Males and Females}

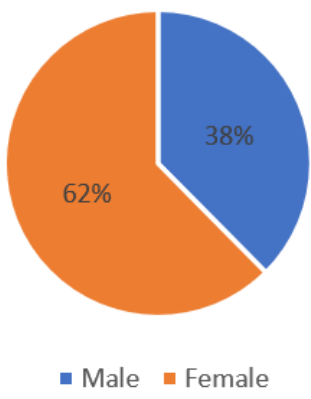

Fig. 3: Percentage of Males and Females participated in the Survey

The experience of students in Microsoft office, internet, email, Blackboard and Banner ranges between $43 \%$ and $62 \%$. The percentages in the table are calculated based on the students and instructors who selected "Strongly Agree" and "Agree" in a 5 point likert-scale. The highest percentage was for word, excel, and power point and this is expected since word is almost used by students and instructors on a daily basis for writing reports, letters, CVs, etc. More, power point is utilized by both instructors and students for delivering presentations, and excel is used for setting up charts, worksheets, and tables. It is for these reasons students are familiar with word, excel, and power point more than teams and streams.

Further, Table I reveals the opinion of the students and instructors toward the benefits of the Blackboard tools such as the announcements, online virtual link which is dedicated for the students to login to the online lecture via Teams or Webex, course syllabus, course documents, assignments, exams, simulation tests, discussion board, video recordings, grade center, resources/links, calendar, and building learning module. Results show that Blackboard tools are beneficial for both instructors and students, since the majority of them indicated that Blackboard tools are beneficial for them. The percentages of the Blackboard tools benefits for students and instructors are between $72.22 \%$ and $100 \%$. More, it is realized that all the instructors $100 \%$ mentioned that the discussion board is beneficial for them. The reason is that they can explore the opinions of their students and enables them to cooperate and collaborate together which makes the course more interesting and adds motivation. With discussion board, shy students who do not participate in F2F discussions, will be able to share their opinions with others online.

\section{B. Second Survey about the Hybrid Learning Experience for Students:}

Table II shows descriptive statistics of the survey performed for the students about The hybrid learning program. In the table, there are items that shows positive impact of HL and there are items that shows negative impact of HL. Similar to table I The percentages of these items are calculated based on the students and instructors who selected "Strongly Agree" 
TABLE I: Descriptive statistics of the surveys performed for the hybrid learning program

\begin{tabular}{|c|c|c|c|c|}
\hline \multirow[t]{2}{*}{ Survey Items } & \multicolumn{2}{|c|}{ Students (BCIS and Computer Fundamentals) } & \multicolumn{2}{|c|}{ Hybrid Learning Instructors } \\
\hline & $\mathrm{N}=116$ & & $\mathrm{~N}=18$ & \\
\hline $\begin{array}{c}\text { Educational Technology } \\
\text { Background }\end{array}$ & Mean (SD) & Percentage & Mean (SD) & Percentage \\
\hline Microsoft Windows & $3.57(0.8)$ & $54.31 \%$ & $4.11(0.87)$ & $66.66 \%$ \\
\hline Microsoft Word & $3.7(0.9)$ & $62 \%$ & $4.55(0.68)$ & $88.88 \%$ \\
\hline Microsoft Excel & $3.72(0.93)$ & $60.34 \%$ & $4.17(0.89)$ & $66.66 \%$ \\
\hline Microsoft Power Point & $3.60(0.94)$ & $55.17 \%$ & $4(0.82)$ & $66.66 \%$ \\
\hline Microsoft Teams & $3.37(0.94)$ & $43.10 \%$ & $4.11(0.74)$ & $77.77 \%$ \\
\hline Microsoft Streams & $3.28(0.92)$ & $44.82 \%$ & $4.39(0.75)$ & $83.33 \%$ \\
\hline Internet & $3.49(0.94)$ & $49.13 \%$ & $4(0.67)$ & $77.77 \%$ \\
\hline Email & $3.5(0.97)$ & $50 \%$ & $4(0.82)$ & $66.66 \%$ \\
\hline Blackboard & $3.45(0.95)$ & $47.41 \%$ & $4.17(0.69)$ & $83.33 \%$ \\
\hline Banner & $3.44(0.95)$ & $46.55 \%$ & $4.17(0.83)$ & $72.22 \%$ \\
\hline Comfort Level with Technology & $3.40(0.94)$ & $44.82 \%$ & $4.33(0.67)$ & $88.88 \%$ \\
\hline \multicolumn{5}{|l|}{ Benefits of Blackboard Tools } \\
\hline Announcements & $4.18(0.77)$ & $77.58 \%$ & $4.39(0.75)$ & $83.33 \%$ \\
\hline Online Virtual Link & $4.29(0.71)$ & $90.51 \%$ & $4.33(0.74)$ & $83.33 \%$ \\
\hline Course Syllabus & $4.33(0.67)$ & $90.24 \%$ & $4.33(0.74)$ & $83.33 \%$ \\
\hline Course Documents & $4.31(0.78)$ & $90.51 \%$ & $4.22(0.85)$ & $72.22 \%$ \\
\hline Assignments & $4.27(0.80)$ & $88 \%$ & $4.39(0.68)$ & $83.88 \%$ \\
\hline Exams & $4.27(0.79)$ & $88.8 \%$ & $4.61(0.59)$ & $94.44 \%$ \\
\hline Simulation Tests & $4.27(0.81)$ & $84.48 \%$ & $4.17(0.83)$ & $72.22 \%$ \\
\hline Discussion Board & $4.28(0.81)$ & $86.20 \%$ & $4.33(0.47)$ & $100 \%$ \\
\hline Video Recordings & $4.29(0.79)$ & $84.48 \%$ & $4.67(0.57)$ & $94.44 \%$ \\
\hline My Grades & $4.30(0.71)$ & $85.34 \%$ & $4.28(0.56)$ & $94.44 \%$ \\
\hline Resources/Links & $4.31(0.63)$ & $90.51 \%$ & $4.28(0.73)$ & $83.33 \%$ \\
\hline Calendar & $4.33(0.72)$ & $85.34 \%$ & $4.33(0.63)$ & $88.88 \%$ \\
\hline Building Learning Module & $4.38(0.66)$ & $89.65 \%$ & $4.5(0.76)$ & $83.33 \%$ \\
\hline
\end{tabular}

Note: These results reveals the percentages of instructors and

students who selected strongly agree or agree in a 5 point likert scale.

and "Agree" in a 5 point likert-scale. We can realize from the results that the majority of the students $82.7 \%$ were satisfied with the existing HL model at CCQ, $81.9 \%$ can control the peace of their own learning, and $84.48 \%$ believed that the online assignments are useful for them in order to understand the course, and that the link between what they study online and in class was clear. Additionally, $89.19 \%$ did not have any difficulty to manage their time for the online part of the course, and more than three quarters of them are encouraged to take a course which involves Blackboard. All these items shows the positive effect of the HL program.

On the other hand, there are items that reveals the negative influence of the HL program such as if the students were finding difficulty in following up with the online course, or if they find that the Blackboard discussion is useless for their online learning, or if they were unable to share ideas with other students online, or if they are spending alot of time online more than F2F class. In our survey, the percentage for students that faced difficulty in the online course is $11.10 \%$ , the students that faced problems in Blackboard discussions represent $6.11 \%$, the students that were unable to share ideas with other students represent $3.4 \%$ and those who prefers to spend the time in class rather than spending too much time online represents $7.15 \%$. These percentages are very low and it can be manageable. Thus, the instructional technology department along with instructors can train and educate these students in order to overcome these issues, especially that these percentages are very low for a HL program. In summary, this survey for students revealed that $76.72 \%$ of the students support the HL process.

\section{Third Survey about the Hybrid Learning Experience for Instructors:}

This study was performed to assess the impact of HL on the instructors and to identify the lecturer's anticipations regarding the enhancement of the HL process as shown in table III. By analyzing the results we realize that $100 \%$ of the instructors participated in this survey were satisfied with the HL program, $88.8 \%$ of them would recommend other teachers to deliver hybrid courses. The majority of the instructors were confident that in the current HL program they can provide effective instruction, motivate students to learn, and assist students who need academic support, with percentages $77.77 \%, 66.66 \%$, and $88.88 \%$ respectively.

More, all of them are feeling flexible with the distance learning tools such as the Microsoft teams and Webex, and 61.11 $\%$ agreed that the HL model is flexible and it impact their lives negatively as well as their social, emotional, and wellbeing $55.55 \%$. Further, $66.66 \%$ of the instructors indicated that the HL model is working properly and they encourage its continuation. However, not all the students participated in their online and F2F classes, and this point needs enhancement.

The encouraging point in the HL model for the instructors is that the performance of the students is very good as indicated by the instructors $83.12 \%$, and the items that shows negative 
TABLE II: Descriptive statistics of the surveys performed for the students about the hybrid learning program

\begin{tabular}{|c|c|}
\hline Survey Items & $\begin{array}{l}\text { Number of Stu- } \\
\text { dents } \\
N=116\end{array}$ \\
\hline \multicolumn{2}{|l|}{ Experience with HL Program } \\
\hline \multicolumn{2}{|l|}{$\begin{array}{c}\text { Items showing positive impact } \\
\text { of HL }\end{array}$} \\
\hline $\begin{array}{l}\text { How satisfied are you with the } \\
\text { current Hybrid learning model at } \\
\text { CCQ? }\end{array}$ & $82.7 \%$ \\
\hline $\begin{array}{l}\text { I can control the peace of my own } \\
\text { learning }\end{array}$ & $81.9 \%$ \\
\hline $\begin{array}{l}\text { Online assignments were helpful } \\
\text { in understanding the course } \\
\text { content }\end{array}$ & $84.48 \%$ \\
\hline $\begin{array}{l}\text { The connection between what I } \\
\text { did online and in class was clear }\end{array}$ & $84.48 \%$ \\
\hline $\begin{array}{l}\text { I Did not have any difficulty } \\
\text { managing my time for the online } \\
\text { part of the course }\end{array}$ & $89.19 \%$ \\
\hline $\begin{array}{l}\text { I would take another course that } \\
\text { incorporates Blackboard }\end{array}$ & $75.86 \%$ \\
\hline \multicolumn{2}{|l|}{$\begin{array}{c}\text { Items showing negative impact } \\
\text { of HL }\end{array}$} \\
\hline $\begin{array}{l}\text { The online course materials were } \\
\text { difficult to follow }\end{array}$ & $11.10 \%$ \\
\hline $\begin{array}{l}\text { I found participating in the online } \\
\text { discussion board useless for my } \\
\text { learning. }\end{array}$ & $6.11 \%$ \\
\hline $\begin{array}{l}\text { I was unable to share ideas with } \\
\text { other students on a regular basis. }\end{array}$ & $3.40 \%$ \\
\hline $\begin{array}{l}\text { The time I spent online would } \\
\text { better have been spent in class. }\end{array}$ & $7.15 \%$ \\
\hline \multicolumn{2}{|l|}{ Recommendation } \\
\hline $\begin{array}{l}\text { I would recommend taking hybrid } \\
\text { courses to other students. }\end{array}$ & $76.72 \%$ \\
\hline
\end{tabular}

impact about the HL program received a very low percentages. Last, $88.17 \%$ of the instructors recommended the HL courses.

\section{Fourth Survey about the Hybrid Learning Experience for Administrators:}

The results of the admin staff survey reveals and acceptable results toward the HL program. These staff are neither instructors, nor students but they participated in the HL survey, some of them have roles such as the higher management, IT team, security, and safety etc. Around $56.5 \%$ were satisfied with the HL program and $77.77 \%$ of them recommended the HL program, $39.13 \%$ were satisfied with the time students are spending at CCQ. Furthermore, the confidence percentage for the admin staff that the teachers can provide effective instruction in the HL model, motivating the students and assisting those who need help were $47.9 \%, 56,5 \%$, and 43.4 $\%$ respectively.

Moreover, around $52.17 \%$ expected that the HL model with have positive impact on the students' social, emotional, and well-being. Add to this, $17.4 \%$ of the admin staff observe that it is easy for them to support their families, friends, and loved ones in the HL model. However, the same percentage
TABLE III: Descriptive statistics of the surveys performed for the instructors about the hybrid learning program

\begin{tabular}{|c|c|}
\hline Survey Items & $\begin{array}{l}\text { Number of In- } \\
\text { structors } \\
\mathrm{N}=18\end{array}$ \\
\hline Experience with HL Program & Percentage \\
\hline \multicolumn{2}{|l|}{$\begin{array}{c}\text { Items showing positive impact } \\
\text { of } \mathrm{HL}\end{array}$} \\
\hline $\begin{array}{c}\text { How satisfied are you with the } \\
\text { current Hybrid learning model at } \\
\text { CCQ? }\end{array}$ & $100 \%$ \\
\hline $\begin{array}{l}\text { I would recommend other teachers } \\
\text { to give hybrid courses. }\end{array}$ & $88.88 \%$ \\
\hline $\begin{array}{l}\text { How confident are you that you } \\
\text { can provide effective instruction } \\
\text { in the current learning model? }\end{array}$ & $77.77 \%$ \\
\hline $\begin{array}{l}\text { How confident are you that you } \\
\text { can motivate your students to } \\
\text { learn in the current model? }\end{array}$ & $66.66 \%$ \\
\hline $\begin{array}{l}\text { How confident are you that you } \\
\text { can help your students who need } \\
\text { the most academic support in the } \\
\text { current learning model? }\end{array}$ & $88.88 \%$ \\
\hline $\begin{array}{l}\text { How easy is it for you to use the } \\
\text { distance learning tools (video } \\
\text { calls, learning applications, etc.)? }\end{array}$ & $100 \%$ \\
\hline $\begin{array}{l}\text { How easy is it to support other } \\
\text { people in your life (family, } \\
\text { friends, loved ones, etc.) with the } \\
\text { current learning model? }\end{array}$ & $61.11 \%$ \\
\hline $\begin{array}{l}\text { What kind of effect is the current } \\
\text { learning model having on your } \\
\text { social emotional well-being? }\end{array}$ & $55.55 \%$ \\
\hline $\begin{array}{l}\text { Is the current learning model } \\
\text { working well and you would like } \\
\text { to see continued? }\end{array}$ & $66.66 \%$ \\
\hline $\begin{array}{c}\text { In the past week, how many of } \\
\text { your students regularly } \\
\text { participated in your virtual } \\
\text { classes? }\end{array}$ & $87.5 \%$ \\
\hline $\begin{array}{l}\text { How about your students } \\
\text { performance in the current } \\
\text { learning model? }\end{array}$ & $83.12 \%$ \\
\hline $\begin{array}{c}\text { In the past week, how engaged } \\
\text { have students been in your F2F } \\
\text { classes? }\end{array}$ & $91.66 \%$ \\
\hline \multicolumn{2}{|l|}{$\begin{array}{c}\text { Items showing negative impact } \\
\text { of } \mathrm{HL}\end{array}$} \\
\hline $\begin{array}{l}\text { I found participation in the online } \\
\text { discussion board useless for the } \\
\text { students. }\end{array}$ & $4.03 \%$ \\
\hline $\begin{array}{l}\text { The time I spent online would } \\
\text { better have been spent in class. }\end{array}$ & $3.02 \%$ \\
\hline $\begin{array}{l}\text { I was unable to share ideas with } \\
\text { the students on a regular basis. }\end{array}$ & $8.12 \%$ \\
\hline $\begin{array}{l}\text { Are there any challenges about } \\
\text { the current learning model that } \\
\text { you would like to see improved? }\end{array}$ & $7 \%$ \\
\hline \multicolumn{2}{|l|}{ Recommendation } \\
\hline $\begin{array}{c}\text { I would recommend other } \\
\text { instructors to give hybrid learning } \\
\text { courses. }\end{array}$ & $88.17 \%$ \\
\hline
\end{tabular}

Note: These results reveals the percentages of Instructors who selected strongly agree or agree in a 5 point likert scale. 
TABLE IV: Descriptive statistics of the surveys performed for the administrators about the hybrid learning program

\begin{tabular}{|c|c|}
\hline Survey Items & $\begin{array}{l}\text { Number of Ad- } \\
\text { ministrators } \\
\mathrm{N}=23\end{array}$ \\
\hline Experience with HL Program & Percentage \\
\hline $\begin{array}{c}\text { How satisfied are you with the } \\
\text { current Hybrid learning model at } \\
\text { CCQ? }\end{array}$ & $56.5 \%$ \\
\hline $\begin{array}{l}\text { How satisfied are you with the } \\
\text { time students are currently } \\
\text { spending for learning personally } \\
\text { at CCQ? }\end{array}$ & $39.13 \%$ \\
\hline $\begin{array}{c}\text { How confident are you that } \\
\text { teachers can provide effective } \\
\text { instruction in the current learning } \\
\text { model? }\end{array}$ & $47.8 \%$ \\
\hline $\begin{array}{l}\text { How confident are you that } \\
\text { teachers can motivate students to } \\
\text { learn in the current model? }\end{array}$ & $56.5 \%$ \\
\hline $\begin{array}{l}\text { How confident are you that } \\
\text { teachers can help students who } \\
\text { need the most academic support } \\
\text { in the current learning model? }\end{array}$ & $43.4 \%$ \\
\hline $\begin{array}{l}\text { Do you expect that the current } \\
\text { learning model will have positive } \\
\text { effect on the student's social } \\
\text { emotional well being? }\end{array}$ & $52.17 \%$ \\
\hline $\begin{array}{l}\text { How easy is it to support other } \\
\text { people in your life (family, } \\
\text { friends, loved ones, etc.) with the } \\
\text { current learning model? }\end{array}$ & $17.4 \%$ \\
\hline $\begin{array}{l}\text { How satisfied are you with the } \\
\text { current learning model that you } \\
\text { wish to continue? }\end{array}$ & $52.17 \%$ \\
\hline $\begin{array}{l}\text { Are there any challenges about } \\
\text { the current learning model that } \\
\text { you would like to see improved? }\end{array}$ & $17.4 \%$ \\
\hline $\begin{array}{l}\text { How convinced are you of the } \\
\text { changes occurring in the Hybrid } \\
\text { learning program? }\end{array}$ & $52.17 \%$ \\
\hline Recommendation & \\
\hline $\begin{array}{l}\text { I would recommend taking hybrid } \\
\text { courses to a friend. }\end{array}$ & $77.77 \%$ \\
\hline
\end{tabular}

of them believe that there are challenges in the HL model and they would like to see it improved. Further, $52.17 \%$ of the administrators are convinced with the changes happening the HL program. Finally, $47.8 \%$ of the admin staff recommended the HL program.

\section{E. Survey Findings and Author's point of View:}

The results of the four surveys were encouraging, since the majority of the participants recommended the HL program and they were satisfied with the HL model. This allows us to identify that the HL strategy is suitable for the students, especially when dealing with COVID19 situation. Further, the didactic tools utilized in the HL process are very important and play a significant role in the success of the program. Based on this, we make sure that we posses and utilize the latest technology in the education process. More, from the survey results we can view that the majority of the students are meeting the learning objectives in the HL program, and those who are not meeting the learning objectives have low percentage and they are being assisted by the instructors and the instructional technology team.

From our point of view, the effective HL environment is significant in guaranteeing innovative educational approaches via the adoption of the latest technology in learning and teaching. There are many key elements that aid in building effective and flexible HL environments such as the inspection about the student's learning outcomes, educational and IT background.

In planning the design, adoption, and implementation of the HL program we are attentive to the implications and indications raised by this survey which is a directional guidance for the design, adoption, and implementation of the HL program. Universities, colleges, and schools in Qatar need to be heedful of the interconnection among the design features, student characteristics and learning outcomes / results which are clear indicators of the effectiveness of the HL program.

Artificial Intelligence (AI) can play a significant role in the success of the HL program. The reason is that it facilitates Asynchronous Learning Activities (ASA) that are suitable for the students' needs, and does not demand constant supervision from the instructors. It assists the learners to get back on track after the summer vacation. Thus, it saves the instructors effort and time which makes HL process more manageable for them. This assists students in getting individualized problems which focuses on the skills that they have difficulty or challenges with it. ASA includes recorded lectures / presentations, discussion boards, videos, slideshows, social media groups, cloud collaborative documents, and email etc. In other words, students can practice in a safe environment without being penalized or losing marks for making mistakes. Thus, instructors can rapidly determine which students are progressing and which students are suffering and need help. This reveals the importance of AI in the HL process.

Furthermore, increasing the quality of HL will contribute to achieving the Sustainable Development Goals (SDGs). The reason is that enhancing the quality of hybrid education will raise up the number of qualified instructors to teach and educate the students. Thus, optimizing the teaching and education quality (SDG 4 - quality education) will help in acheiving other objectives such as increasing the high-skilled workforce staff. This will result in productive employment, which in turn reinforces the economic growth (SDG 8 - economic growth), and build powerful and robust institutions (SDG16 - strong growth). In summary, fulfilling the SDGs in hybrid education is challenging, but with reliable findings, solid plan, optimal design for learning environment, and top-quality teachers for HL program this challenge can be controlled.

\section{CONClusion And Future Education RECOMMENDATIONS}

This research study on HL offers valuable insight regarding research related to HL program in Qatar. However, this study constructed the factors that affects the students, instructors, and administrators toward adopting HL program. Thus, a 
questionnaire survey was employed as a research method for data collection. The surveys were carried out in CCQ and it identified the factors that affect the perception of administrators, students, and instructors readiness towards HL adoption. These factors can be utilized to develop and build a model to examine instructors, students, and administrators simultaneously towards HL adoption and implementation in Qatar and countries abroad.

Nonetheless, this is a small-scale research study that involves 157 participants from CCQ HL program. Thus, the findings in this research paper cannot be generalized, especially that all the participants were from the same college and the HL process at CCQ is still at its infancy. Therefore, our future work is anticipated to be conducted on a large scale including multiple colleges, schools, and universities inside and outside Qatar in order to investigate the opinion of students about the HL program. Currently, in our study we included factors and elements related to the informational technology background of the students and instructors, as well as their experience in the HL program. More, we involved a sample from the admin staff to participate in our survey. However, in our future study we will make sure to explore each item mentioned in this survey in details, and include another new items related to the HL process.

Furthermore, in addition to the surveys, we will include case studies and F2F interviews with students, in-depth literature reviews about hybrid and blended learning, experimental methods which involves learning management system (LMS) dataset, and we will discuss the importance of the AI, machine learning (ML), and Sustainability in the HL process. Therefore, it is anticipated that our large-scale research study would generate reliable findings in the area of HL education. In our point of view, in future research we need to fully include plentiful determinants of learning and teaching hybrid courses.

\section{REFERENCES}

[1] Arnab, Sylvester, "In Support of COIVD-19 Global Education Coalition Launched by UNESCO", version 2 in December 2020.

[2] C. R. Graham, "Blended learning systems: Definition, current trends, and future directions". In C. J. Bonk and C. R. Graham (Eds.). Handbook of blended learning: Global perspectives, local designs (pp. 3-21). San Francisco: Pfeiffer Publishing 2005.

[3] Community College of Qatar (CCQ) Website, "CCQ to offer its Associate of Business Administration in a hybrid format", 13 April 2020, [Online]. Available: https://www.ccq.edu.qa/English/MediaCenter/ News/Pages/Details.aspx?NewsID $=306$.

[4] B. Allan, "Blended learning: Tools for teaching and training". London: Facet Publishing 2006.

[5] Qiuyun Lin, "Student Views of Hybrid Learning: A One-Year Exploratory Study". Journal of Computing in Teacher Education Volume 25 / Number 2 Winter 2008-2009.

[6] D. Ifenthaler, and C. Widanapathirana, "Development and validation of a learning analytics framework: Two case studies using support vector machines. Technology, Knowledge and Learning", 19 (1-2), 221-240, 2014.

[7] M. A. S. Mustapa, M. Ibrahim, and A. Yusoff, "Engaging vocational college students through blended learning: Improving class attendance and participation. Procedia-Social and Behavioral Sciences", 204, 127-135, 2015.

[8] Z. Sun, and X. Qiu, "Developing a blended learning model in an EFL class. International Journal of Continuing Engineering Education and Life Long Learning, 27(1-2), 4-21, 2017.
[9] C. R. Graham, W. Woodfield, and J. B. Harrison,"A framework for institutional adoption and implementation of blended learning in higher education. The Internet and Higher Education", 18, 4-14, 2013.

[10] C. R. Graham, "merging practice and research in blended learning. Handbook of Distance Education" 3, 333-350, 2013.

[11] B. Anthony, M. A. Majid, and A. Romli, "Green information technology system practice for sustainable collaborative enterprise: A structural literature review". International Journal of Sustainable Society, 9(3), 242-272, 2017.

[12] B. Anthony, A. Kamaludin, A. Romli, A. F. M. Raffei, A. Abdullah, G. L Ming,"Exploring the role of blended learning for teaching and learning effectiveness in institutions of higher learning: An empirical investigation. Education and Information Technologies", 24(6), 3433-3466, 2019.

[13] Sun, Z., and Qiu, X.,'Developing a blended learning model in an EFL class. International Journal of Continuing Engineering Education and Life Long Learning", 27(1-2), 4-21, 2017.

[14] S. Van Laer, and J. Elen, "Adults' self-regulatory behaviour profiles in blended learning environments and their implications for design. Technology, Knowledge and Learning", 25, 509-539, 2020.

[15] Microsoft Education Website, "Breakout Rooms: Now available in Microsoft Teams", 12 January, 2021, [Online]. Available: https://educationblog.microsoft.com/en-us/2021/01/breakout-roomsnow-available-in-microsoft-teams

[16] Cisco Website, "Establish Hybrid Learning Environments", 12 January, 2021, [Online]. Available: https://www.cisco.com/c/en/us/solutions/industries/education/virtualclassroom.html 